\section{'Chickasaw' Blackberry}

John R. Clark ${ }^{1}$ and James N. Moore ${ }^{2}$

Department of Horticulture, University of Arkansas, Fayetteville, AR 72701

Additional index words. Rubus, fruit breeding

'Chickasaw' is the tenth release in a series of erect-growing, high-quality, productive blackberry (Rubus L. subgenus Rubus Watson) cultivars developed by the Univ. of Arkansas. 'Chickasaw' produces larger fruit, has comparable to higher yields, and has better postharvest handling characteristics than 'Shawnee', the current thorny, erect cultivar with a similar season of ripening.

\section{Origin}

'Chickasaw' resulted from a cross of Ark. $842 \times$ Ark. 1246 made in 1985 (Fig. 1). The original plant was selected in 1988 from a seedling field at the Univ. of Arkansas Fruit Substation, Clarksville. 'Chickasaw', tested as selection A-1647, has been evaluated most thoroughly at this location. A single, 6.1-m plot was established at this location in 1988 and collection of observational data on this plot began at fruiting in 1990 and continued through 1998. Plots of the thorny cultivars Choctaw, Kiowa, and Shawnee were also present in this planting and data were collected on these during this period. Soluble solids concentration was measured on a 25-berry sample collected one time each season for 8 years, 1990-95, 1997, and 1998, using a handheld refractometer. Fruit ratings included firmness (as measured subjectively by hand in the field on eight to ten berries, with rating of 10 indicating very firm) and flavor (subjectively rated by tasting berries in the field). Plant ratings were conducted one time each year for 9 years (1993-98) during the fruiting season, for vigor ( 1 to 10 with a rating of 7 to 10 acceptable), health ( 1 to 10 with $10=$ excellent health as reflected by freedom from diseases and overall plant appearance), and erectness ( 1 to 10 with $10=$ very erect). Winter injury ratings were conducted in late April to early May for 8 years, using a scale of 1 to 10 with $10=$ no injury. Additionally, replicated trials

Received for publication 14 Dec. 1998. Accepted for publication 13 Apr. 1999. Published with approval of the Director, Arkansas Agricultural Experiment station, manuscript no. 98098 . We thank Kenda Woodburn, Jack Young, Andy Allen, Effie Gilmore, David Gilmore, Paula Watson, Gina Fernandez, Kelly Irvin, and Maurus Brown for assistance in data collection during the evaluation of 'Chickasaw'. Additionally, appreciation is expressed to P. Perkins-Veazie and J. Collins (USDA-ARS) for postharvest evaluation of 'Chickasaw'. The cost of publishing this paper was defrayed in part by the payment of page charges. Under postal regulations, this paper therefore must be hereby marked advertisement solely to indicate this fact.

${ }^{1}$ Associate Professor.

${ }^{2}$ Distinguished Professor Emeritus. were established at research stations in Clarksville [Fruit Substation, west-central, U.S. Dept. of Agriculture (USDA) hardiness zone 7a], Hope (Southwest Research and Extension Center, USDA hardiness zone 8a), and Fayetteville (Arkansas Agricultural Research and Extension Center, northwest, USDA hardiness zone 6b), Ark., in 1996. 'Chickasaw' and the three other cultivars were included in the trials at Fayetteville and Hope, while 'Kiowa' was absent from the replicated trial at lications each of 'Chickasaw', 'Choctaw', and 'Shawnee'. Only two replications of 'Kiowa' were included at Hope, and four replications at Fayetteville. Each 3.1-m replication was established using five root cuttings spaced $0.6 \mathrm{~m}$ apart. Data for $10 \%$ and $50 \%$ bloom, and first, Clarksville. These trials consisted of four rep-

Fig. 1. Pedigree of 'Chickasaw' blackberry. peak (the date when the highest percentage of the total fruit yield was harvested), and last harvest dates were recorded for 1997 and 1998 and averaged for the replicated plots at Clarksville, and for 1998 only at Hope. Also, 25-berry samples were collected from the four replications at Clarksville on one harvest date in 1998, seeds extracted from the berries using a blender, 100-seed samples collected and weighed (fresh weight after only surface drying of the seeds, and dry weights after heating at $70{ }^{\circ} \mathrm{C}$ for $24 \mathrm{~h}$ ), and average seed weight calculated. Total yield and average berry weight (with average berry weights determined from 25 berries/replicate on each harvest date at each location, and the average for each replicate for the season used in the analysis) data from the replicated plantings for 1997 and 1998 for all locations and years were analyzed individually as a randomized complete block using the GLM procedure of SAS (SAS Institute, 1989). The individual year and location analyses were conducted because of differences in variations in the data among locations and years, especially for yield, which made inappropriate a multi-year, multi-location single analysis of variance. Seed weight data from 1998 from Clarksville only were ana-

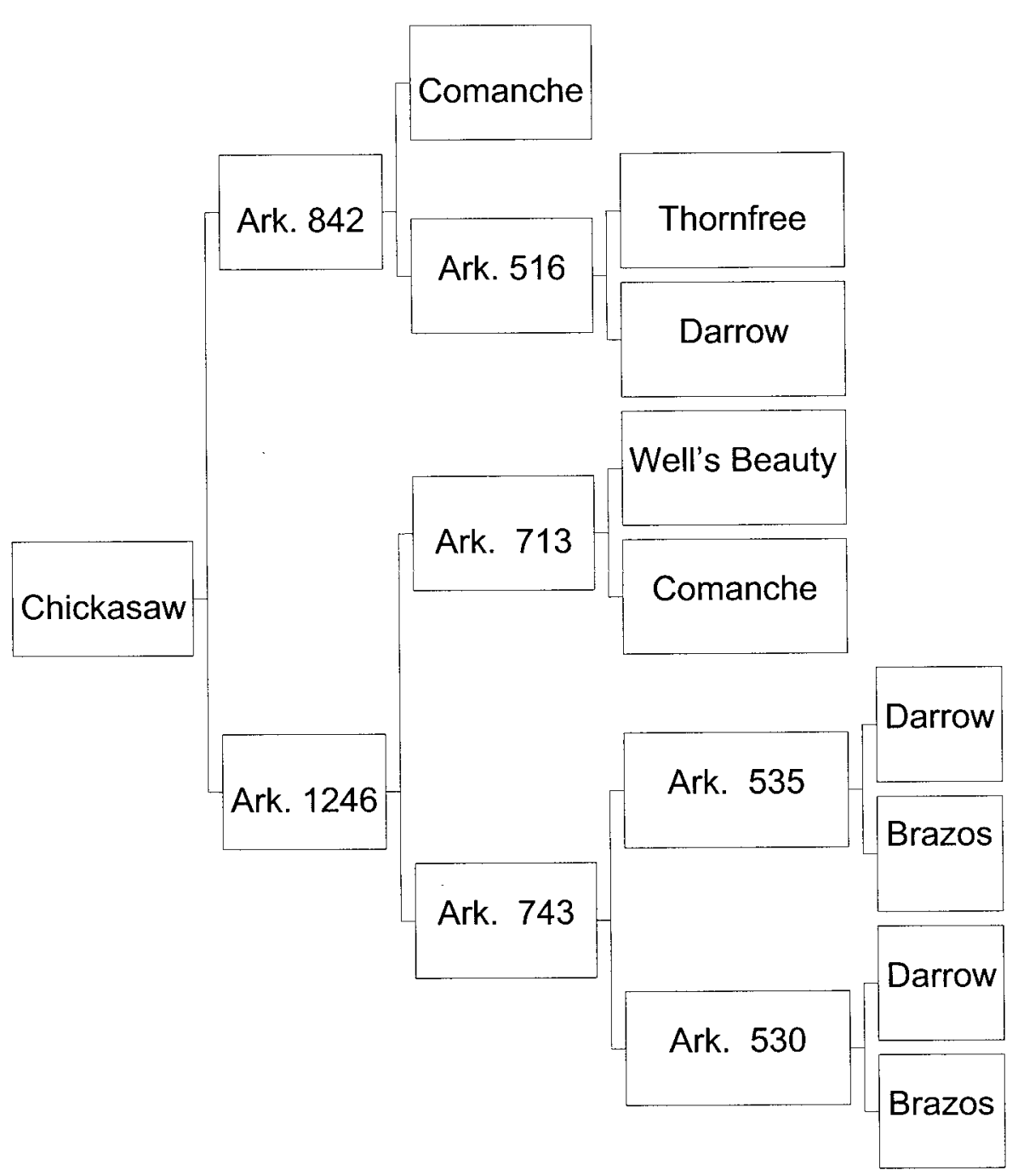


lyzed as a randomized complete block. All mean separations were by $t$ test $(P \leq 0.05)$. In all plantings, standard cultural practices for erect blackberry production were used, including annual preemergence and postemergence herbicide applications, annual spring nitrogen fertilization $\left(56 \mathrm{~kg} \cdot \mathrm{ha}^{-1}\right.$ of $\left.\mathrm{N}\right)$ using ammonium nitrate, summer tipping of primocanes at $1.1 \mathrm{~m}$, and dormant pruning. All plantings received a single application of liquid lime sulfur at budbreak for control of anthracnose [Elsinoe veneta (Burkh.) Jenkins].

\section{Description and performance}

'Chickasaw' produced the highest yields and appeared to be equally productive in replicated trials at each of the three locations (Table 1). Yields were usually not statistically different from those of 'Shawnee' in most comparisons, and from those of 'Kiowa' in two of four comparisons (Table 1). Note that the yield data are from the first (1 year after fruiting and on semi-erect canes) and second (erect canes) fruiting years. However, the yields recorded in 1998 are among the higher yields recorded in Arkansas in any cultivar trials of thorny, erect cultivars.

Fruit weight of 'Chickasaw' was greater than 'Choctaw' and 'Shawnee' in all but one comparison, and similar to that of 'Kiowa' at Fayetteville(Table 1). 'Chickasaw' maintained very good fruit weight over the harvest season (data not shown). In 1997, the first fruiting season, the average fruit weight of 'Chickasaw' for the season at Clarksville was $11.0 \mathrm{~g}$ (Table 1 ), and the lowest average fruit weight recorded was $8.0 \mathrm{~g}$ at the last harvest date. In 1998 , with an average of $10.5 \mathrm{~g}$ (Table 1), the lowest fruit weight recorded during the harvest season was $9.3 \mathrm{~g}$. 'Chickasaw' has excellent flower and fruit fertility and full drupelet set (data not shown).

On average, 'Chickasaw' bloomed 1 to $3 \mathrm{~d}$ later than 'Choctaw', $4 \mathrm{~d}$ before 'Shawnee' and $3 \mathrm{~d}$ before 'Kiowa' (Table 2). First harvest date for 'Chickasaw' averaged $10 \mathrm{~d}$ later than 'Choctaw' and $3 \mathrm{~d}$ later than 'Shawnee' and 'Kiowa' (Table 2). Peak harvest date of 'Chickasaw' was $1 \mathrm{~d}$ later than that of 'Shawnee' at Clarksville and $7 \mathrm{~d}$ later than that of 'Shawnee' and 'Kiowa' at Hope. Average length of fruiting period for 'Chickasaw' was $40 \mathrm{~d}$ vs. $32 \mathrm{~d}$ for 'Choctaw', $43 \mathrm{~d}$ for 'Kiowa', and $38 \mathrm{~d}$ for 'Shawnee'.

Fruit of 'Chickasaw' are long, cylindrical, and slightly flattened in shape and very attractive with a glossy, black finish. Primary fruit diameter is $2.6 \mathrm{~cm}$ and berry length averages $4.1 \mathrm{~cm}$. Average fruit weight of primary fruit in 1998 was $11.4 \mathrm{~g}$, secondary $11.0 \mathrm{~g}$, and tertiary $10.7 \mathrm{~g}$, reflecting a consistently large fruit size among these locations on the inflorescence. Fruits per inflorescence averaged 6 with a range of 4 to 19 . Fruit firmness was higher for 'Chickasaw' than for 'Shawnee' or 'Choctaw' but comparable to 'Kiowa' (Table 3). Soluble solids concentration of 'Chickasaw' averaged $9.6 \%$ over 8 years (Table 3 ). Flavor of 'Chickasaw' was rated higher than that of 'Kiowa' or 'Shawnee' but lower than that of
Table 1. Yield and berry weight of blackberry cultivars at three locations in Arkansas from plantings established in 1996.

\begin{tabular}{|c|c|c|c|c|}
\hline \multirow[b]{2}{*}{ Cultivar } & \multicolumn{2}{|c|}{ Yield $\left(\mathrm{kg} \cdot \mathrm{ha}^{-1}\right)$} & \multicolumn{2}{|c|}{ Berry wt (g) } \\
\hline & 1997 & 1998 & 1997 & 1998 \\
\hline \multicolumn{5}{|c|}{ Clarksville } \\
\hline Chickasaw & $12,321 \mathrm{a}^{\mathrm{z}}$ & $11,085 \mathrm{a}$ & $11.0 \mathrm{a}$ & $10.5 \mathrm{a}$ \\
\hline Choctaw & $7,471 \mathrm{a}$ & $7,972 \mathrm{a}$ & $6.1 \mathrm{c}$ & $5.4 \mathrm{c}$ \\
\hline Shawnee & $8,912 \mathrm{a}$ & $8,417 \mathrm{a}$ & $8.4 \mathrm{~b}$ & $7.4 \mathrm{~b}$ \\
\hline \multicolumn{5}{|c|}{ Hope } \\
\hline Chickasaw & $7,869 \mathrm{a}$ & $17,154 \mathrm{a}$ & $8.8 \mathrm{a}$ & $8.5 \mathrm{a}$ \\
\hline Choctaw & $4,292 \mathrm{~b}$ & $10,150 \mathrm{~b}$ & $5.3 \mathrm{c}$ & $4.3 \mathrm{c}$ \\
\hline Kiowa & $992 \mathrm{c}$ & $11,139 \mathrm{~b}$ & $7.3 \mathrm{~b}$ & $7.8 \mathrm{~b}$ \\
\hline Shawnee & $4,223 \mathrm{~b}$ & $17,090 \mathrm{a}$ & $7.3 \mathrm{~b}$ & $6.3 \mathrm{~b}$ \\
\hline \multicolumn{5}{|c|}{ Fayetteville } \\
\hline Chickasaw & $11,491 \mathrm{a}$ & $11,239 \mathrm{a}$ & $10.2 \mathrm{a}$ & $8.3 \mathrm{a}$ \\
\hline Choctaw & $4,010 \mathrm{~b}$ & $6,695 b$ & $5.3 \mathrm{~b}$ & $3.3 \mathrm{c}$ \\
\hline Kiowa & $9,832 \mathrm{a}$ & $10,016 \mathrm{ab}$ & $10.0 \mathrm{a}$ & $8.1 \mathrm{ab}$ \\
\hline Shawnee & $8,126 \mathrm{ab}$ & $8,839 \mathrm{ab}$ & $7.9 \mathrm{a}$ & $5.4 \mathrm{~b}$ \\
\hline
\end{tabular}

${ }^{\mathrm{z}}$ Mean separation within columns and locations by $t$ test $(P \leq 0.05)$.

Table 2. Bloom and fruit maturity dates of blackberry cultivars at two locations in Arkansas from plantings established in 1996.

\begin{tabular}{|c|c|c|c|c|}
\hline Characteristic & Chickasaw & Choctaw & Kiowa & Shawnee \\
\hline \multicolumn{5}{|c|}{ Clarksville } \\
\hline \multicolumn{5}{|l|}{ Bloom date ${ }^{z}$} \\
\hline $10 \%$ bloom & 25 Apr. & 23 Apr. & --- & 29 Apr. \\
\hline $50 \%$ bloom & 29 Apr. & 30 Apr. & --- & 6 May \\
\hline \multicolumn{5}{|l|}{ Harvest date ${ }^{z}$} \\
\hline First & 10 June & 30 May & --- & 7 June \\
\hline Peak $^{y}$ & 21 June & 7 June & --- & 20 June \\
\hline Last & 20 July & 1 July & --- & 17 July \\
\hline \multicolumn{5}{|c|}{ Hope } \\
\hline \multicolumn{5}{|l|}{ Bloom date } \\
\hline $10 \%$ bloom & 14 Apr. & 13 Apr. & 16 Apr. & 15 Apr. \\
\hline $50 \%$ bloom & 18 Apr. & 15 Apr. & 21 Apr. & 21 Apr. \\
\hline \multicolumn{5}{|l|}{ Harvest date ${ }^{\mathrm{x}}$} \\
\hline First & 29 May & 20 May & 26 May & 26 May \\
\hline Peak $^{y}$ & 22 June & 1 June & 15 June & 15 June \\
\hline Last & 6 July & 22 June & 8 July & 29 June \\
\hline
\end{tabular}

${ }^{\mathrm{z}}$ Average of 2 years, 1997 and 1998.

yeak harvest was the date at which the highest percentage of the total crop was harvested.

${ }^{x}$ Data from 1 year, 1998.

Table 3. Fruit and plant characteristics of blackberry cultivars at the Univ. of Arkansas Fruit Substation, Clarksville.

\begin{tabular}{|c|c|c|c|c|}
\hline Characteristics & Chickasaw & Choctaw & Kiowa & Shawnee \\
\hline \multicolumn{5}{|l|}{ Fruit } \\
\hline Firmness ${ }^{\mathrm{z}, \mathrm{y}}$ & 7.9 & 7.1 & 7.8 & 7.1 \\
\hline Flavor $^{z, y}$ & 8.1 & 8.6 & 7.6 & 7.4 \\
\hline $\begin{array}{l}\text { Seed fresh weight } \\
(\mathrm{mg} / \mathrm{seed})\end{array}$ & $9.1 \mathrm{a}^{\mathrm{x}}$ & $6.5 \mathrm{~b}$ & --- & $8.8 \mathrm{a}$ \\
\hline $\begin{array}{l}\text { Seed dry weight } \\
(\mathrm{mg} / \mathrm{seed})\end{array}$ & $4.1 \mathrm{a}^{\mathrm{x}}$ & $2.2 \mathrm{~b}$ & --- & $3.7 \mathrm{a}$ \\
\hline Soluble solids $(\%)^{\mathrm{w}}$ & 9.6 & 8.7 & 9.7 & 9.3 \\
\hline \multicolumn{5}{|l|}{ Plant } \\
\hline Vigor $^{z, y}$ & 8.9 & 8.0 & 8.1 & 9.0 \\
\hline Health $^{\text {z,y }}$ & 8.7 & 8.1 & 8.3 & 8.4 \\
\hline Erectness ${ }^{\mathrm{z}, \mathrm{y}}$ & 8.6 & 8.6 & 7.0 & 9.3 \\
\hline Winter injury ${ }^{z, v}$ & 8.8 & 7.9 & 8.5 & 8.6 \\
\hline
\end{tabular}

${ }^{2}$ Rating scale of 1 to 10 where $10=$ best. For the various characteristics, the following apply: firmness was rated in the field, with $10=$ very firm; flavor was also rated in the field with $10=$ excellent flavor; vigor was rated at harvest with 7 to 10 as acceptable vigor with $10=$ higher vigor than lower scores; health rating was at harvest and was based on the plant's freedom from diseases and overall plant appearance where $10=$ excellent health; erectness reflects uprightness of the canes where $10=$ very erect and was rated at harvest; winter injury reflects cane or other injury from exposure to cold conditions where $10=$ no injury, and was rated in late April to early May each year. All ratings for these variables were conducted on observational plots.

y Means of 9 years, 1990 through 1998.

${ }^{x}$ Data from 1998; mean separation within row by $t$ test $(P \leq 0.05)$; data are an average weight of 100 seeds from each replication collected from fresh seeds or after drying for $24 \mathrm{~h}$ at $70{ }^{\circ} \mathrm{C}$.

wMeans of 8 years, 1990 through 1995, 1997, and 1998; soluble solids concentration was measured from a single 25 -fruit sample collected each year from the observational plots and determined by a hand-held refractometer.

vMeans of 8 years, 1990, 1991, and 1993 through 1998. 
'Choctaw' (Table 3). Postharvest evaluations indicated that overall 'Chickasaw' was superior in storage to 'Shawnee', specifically performing better than 'Shawnee' in percentage of leaky fruit and soft berries (P. PerkinsVeazie, personal communication). 'Chickasaw' experienced more drupelet reddening than 'Shawnee' during fruit storage (P. Perkins-Veazie, personal communication). 'Chickasaw' did not perform as well as 'Navaho' in postharvest evaluations, and should not be expected to handle as well as 'Navaho'. Seed weight of 'Chickasaw' was similar to that of 'Shawnee' but heavier than that of 'Choctaw' (Table 3).

Canes of 'Chickasaw' are spiny (thorny) and have a spine density similar to that of 'Shawnee' but less than that of 'Kiowa'. 'Chickasaw' was rated similar to 'Choctaw' in cane erectness, more erect than 'Kiowa', and slightly less erect than 'Shawnee' (Table 3). 'Chickasaw' can be grown in a hedgerow without trellis support, with primocanes tipped at $1.1 \mathrm{~m}$ to control primocane length and encourage lateral branching. Vigor and health of 'Chickasaw' were rated high, similar to 'Shawnee' and higher than 'Choctaw' and
'Kiowa' (Table 3). Ratings for winter injury for 'Chickasaw' have been comparable to those for 'Shawnee' and 'Kiowa' and slightly higher than those for 'Choctaw' (Table 3). Minimum low temperatures experienced at Clarksville during the winters of 1989-90, 1990-91,1991-92, 1992-93, 1993-94, 199495, 1995-96, 1996-97, and 1997-98 were $22.6,-13.9,-12.2,-5.6,-12.8,-10.5,-17.2$, -12.2 , and $-6.6^{\circ} \mathrm{C}$, respectively. Additionally, in 1996 a spring freeze $\left(-12.2^{\circ} \mathrm{C}\right)$ occurred near budbreak on 10 Mar. and probably further damaged the cultivars. Sprouting of root cuttings of 'Chickasaw' has been good as evidenced by good stand establishment in the replicated trials.

'Chickasaw' is moderately resistant to anthracnose. Anthracnose was observed only in 1997 on early-ripening berries. No orange rust [Gymnoconia nitens (Shwein.) F. Kern \& H.W. Thurston] has been observed on 'Chickasaw' in any plantings. Resistance of 'Chickasaw' to rosette/double blossom [Cercosporella rubi (Wint.) Plakidas] has not been determined. Slight evidence of powdery mildew [Sphaerotheca macularis (Wallr.:Fr.) Lind] infections (some leaf curling) were observed in 1993 and 1997, but no damage to the plants (defoliation, loss of leaf health) was noted.

Outstanding characteristics of 'Chickasaw' include large fruit, high yields, good fruit quality, improved postharvest performance over 'Shawnee', and vigorous, healthy, erect plants. 'Chickasaw' should be popular as a commercial cultivar, as well as an option for home gardens. 'Chickasaw' is expected to perform well in areas where 'Shawnee', 'Choctaw', or 'Kiowa' are adapted, including all areas of the South and into the Midwest, in addition to the West and Pacific Northwest.

\section{Availability}

An application for a U.S. plant patent has been filed for 'Chickasaw'. A list of nurseries licensed to propagate and sell 'Chickasaw' can be obtained from J.R.C., 316 Plant Science, Dept. of Horticulture, Univ. of Arkansas, Fayetteville, AR 72701.

\section{Literature Cited}

SAS Institute. 1989. SAS/STAT user's guide, version 6, 4th ed. vol. 2. SAS Inst., Cary, N.C. 